\title{
The Effect of Drinking Turmeric Stew Towards Reducing Dysmenorrheal Pain Scale on Students of Senior High School 1 of East Pamona, Poso Regency
}

\author{
Adrian Sali $^{1^{*}}$, Muhammad Risal ${ }^{2}$ \\ ${ }^{1}$ Nursing Science Study Program, STIKES Bataraguru Soroaka, East Luwu \\ ${ }^{2}$ Nursing Science Study Program, STIKES Bataraguru Soroaka, East Luwu \\ *Email: adriansali37@gmail.com
}

\begin{abstract}
Menstrual pain, or dysmenorrhea, is a problem that practically all women, regardless of age, suffer during their menstrual cycle. However, the adolescent age group has the highest prevalence of women experiencing this. The symptoms of dysmenorrhea include pain in the lower abdomen extending to the waist that typically begins 2-3 days before menstruation and lasts for 1-2 days throughout menstruation, along with certain associated symptoms such as heartburn, pains, or prickles: (Gant et al.,2016) The purpose of this study is to assess the effect of turmeric stew on the pain scale used to diagnose dysmenorrhea in students attending Senior High School 1 East Pamona, Poso Regency. With a total of 34 respondents, this study used the Quasy Experiment method with a non-randomized control group pre-posttest design and a purposive sampling strategy. The study's data were gathered utilizing general data collection sheets and NRS pain scale measurement sheets (Numeric Rating Scale). The Wilcoxon Signed Rank Test and the Mann Whitney U-Test were used to analyze the data. Before drinking turmeric stew, both the treatment and control groups had moderate pain. Meanwhile, the average pain intensity after drinking the turmeric stew was $68.8 \%$ mild pain and $31.2 \%$ no pain in the treatment group, and $37.5 \%$ mild discomfort and $62.5 \%$ moderate pain in the control group. Following statistical analysis with the Wilcoxon Signed Rank Test, a p-value of $0,000 \leq \alpha 0,05$ was achieved, showing that turmeric stew affected both groups. Additionally, a statistical test utilizing the Mann-Whitney U-Test yielded a value of $0,000 \leq \alpha 0,05$, showing a significant difference in pain scale reduction between the treatment and control groups. To summarize, ingesting turmeric stew has a substantial effect on lowering the pain scale for dysmenorrhea in students.
\end{abstract}

Keywords: Turmeric Stew, Dysmenorrhea, High School, Students

\section{Introduction}

Adolescence will begin with puberty, which will begin with the formation of secondary sex traits and terminate with the development of reproductive capacity, depending on the individual. Adolescents go through a period of physical, emotional, and social transformation as a result of the onset of puberty. The rapid growth of adolescents, the puberty defined by the onset of menstruation, as well as environmental and dietary conditions are all factors to consider: (Kusmiran et al., 2014).

Menstrual cramps, also known as dysmenorrhea, are a type of disease that affects nearly all women during their period. Whatever their age, the age group of early teens who have just undergone menarche has the highest number of women who suffer from this condition regardless 
of their age. Pain in the lower abdomen to the waist that usually begins 2-3 days before menstruation and lasts for 1-2 days during menstruation, with features of pain such as heartburn, aches, or prickles, are the most frequently observed symptoms.

According to the World Health Organization, there have been a total of 1,769,425 (90 \%) cases, with 10-15\% of them experiencing dysmenorrhea. Primary dysmenorrhea is quite common in Asian countries, with the highest frequency being found in Taiwan, where $75.2 \%$ of the population suffers from the condition. The prevalence rate in Malaysia is $50.9 \%$, according to the data. According to the World Health Organization, $54.89 \%$ of women in Indonesia suffer from primary type dysmenorrhea, with the remaining population suffering from secondary type dysmenorrhea. With a prevalence ranging from 43-93 \% in teens, dysmenorrhea is common within this age group: (WHO., 2013).

The treatment of menstruation pain (dysmenorrhea) can be accomplished through the administration of analgesics, anti-inflammatory medicines, and herbal medicine therapy, which is derived from plant materials and has been shown to be effective. Turmeric, tamarind, cinnamon, cloves, and ginger are some of the plants that are believed to have pain-relieving properties: (Anurogo et al., 2011).

The prevalence of dysmenorrhea is extremely high around the world. Women in each country suffer from dysmenorrhea at a rate of approximately $50 \%$ on average. 4 According to a study conducted in Sweden, 80\% of adolescents between the ages of 19 and 21 years old suffer from dysmenorrhea. Furthermore, $15 \%$ of women restrict their regular activities during menstruation and require medication to alleviate dysmenorrhea. Additionally, 8-10\% of students do not attend or do not attend school as a result of this issue: (Desfietni.,2012).

In Indonesia, the incidence of dysmenorrhea is $54.89 \%$ primary dysmenorrhea and 9.36\% secondary dysmenorrhea, according to the World Health Organization. When it comes to pubertal adolescents, the incidence of dysmenorrhea ranges from $45 \%$ to $75 \%$, depending on the study. Because of this, students have missed school between 13 and $51 \%$ of the time, with the majority of those missing school between 5 and $14 \%$ due to the intensity of symptoms that have occurred. As a result, dysmenorrhea is the most common reason for absence among adolescent girls: (Riskesdas., 2013).

Researchers Utami and colleagues conducted a study on high school students in Bone Regency, South Sulawesi, and discovered that $87.1 \%$ of teenagers suffered from dysmenorrhea. Likewise, research conducted by Pundari et al., on students at the General Sudirman University found $67.1 \%$ of dysmenorrheal adolescents. Sophia and colleagues conducted a study with pupils from the Medan Vocational School. According to the findings of the study, dysmenorrhea affects $81.30 \%$ of the population. In a comparable study conducted by Kusuma EP among high school students in Semarang, the incidence of dysmenorrhea was found to be as high as $68 \%$ in some participants. Similar findings emerged from Kusumawati's research, which was conducted at a high school in Pekan Baru, where she discovered that $87 \%$ of the students had dysmenorrhea. When it comes to gynecological issues, dysmenorrhea is among the most frequent. It can affect more than half of all women, making it difficult to carry out everyday activities for one to three 
days each month. In primary dysmenorrhea, the absence of adolescence at school is one of the most prevalent problems that arise, accounting for around $25 \%$ of all such cases: (Reeder et al., 2011).

The world's traditional medicine continues to progress slowly, owing to chemical drugs' numerous flaws. For example, chemical medications frequently cause adverse effects, either directly or by accumulation. On the contrary, therapeutic plants and herbs offer benefits that pharmaceuticals do not. If medicinal herbs are ingested according to the formula, they have extremely few negative effects. Additionally, the expensive cost of chemical drug treatment motivates people to seek alternative treatment through traditional medicine: (Febriana et al., 2013). Furthermore, turmeric includes curcumin and essential oils that have a similar effect to analgesic medicines in lowering dysmenorrhea discomfort. Turmeric works by suppressing the biosynthesis of prostaglandins, so blocking pain signals emanating from the pain cortex in the medulla oblongata. Based on the foregoing, the authors would like to conduct a study on the effect of drinking turmeric stew on reducing the pain scale of dysmenorrhea in students from Senior High School 1 East Pamona, Poso Regency.

\section{Materials and Methods}

The researchers used a quasi-experimental approach with a non-equivalent control group. Subjects were placed into two groups for this study: the treatment group and the control group. All of which would be subjected to a pre- and post-test. Purposive sampling was utilized in this study, which is a sampling approach that involves picking samples according to the researcher's desired inclusion and exclusion criteria (depending on the study's objectives/problems). The sample for this study consisted of 34 female high school students in East Pamona who had dysmenorrhea. Additionally, bivariate analysis was performed using the Wilcoxon Signed Rank Test ( $\mathrm{p}$ 0.05) with an error rate of $\alpha 0.05$ using the SPSS 22 program. The goal of this study was to investigate the effect of turmeric stew on the dysmenorrhea pain scale. The Wilcoxon test is a statistical procedure used to compare pre- and post-intervention data. If the P-value is less than $0.05, \mathrm{H} 0$ is ruled out. This indicates that the pain scale decreases before and following consumption of turmeric stew, and vice versa. Furthermore, if the P-value is greater than 0.05, $\mathrm{H} 0$ is accepted. This indicates that there is no difference in pain scores between before and after consuming turmeric stew. The Mann-Whitney U-Test was used to determine the difference between the control and treatment groups. This test compares and ranks the ordinal scores of two independent data variables.

\section{Results and Discussions}

The study's findings suggested that consuming turmeric stew had a beneficial effect on reducing the pain scale associated with dysmenorrhea in 34 students from Senior high school 1 East Pamona, Poso Regency. 
Table 1. Characteristics of Respondents Based on Age

\begin{tabular}{crcccc}
\hline Variable & $\mathbf{N}$ & Mean & Median & Modus & Min-Max \\
\hline $\begin{array}{c}\text { Age } \\
\text { Respondents }\end{array}$ & 34 & 16,84 & 17.00 & 17 & $16-18$ \\
\hline
\end{tabular}

According to Table 1, the average age of responders is 16.58 years, with a median of 17 . The majority of responses are 17 years old. The youngest is 16 years old, and the oldest is 18 .

Table 2.

Frequency Distribution of Respondents Based on Menstruation Length

\begin{tabular}{clcl}
\hline No & Duration & Frequency & Percentage $(\boldsymbol{\%})$ \\
\hline 1 & $\leq 7$ hari & 14 & 41,1 \\
2 & $\leq 7$ days & 20 & 58,9 \\
Total & & 34 & 100 \\
\hline
\end{tabular}

According to Table 2, the majority of respondents (20 students or $58.9 \%$ ) reported menstruation lasting more than seven days, whereas a few (14 students or 41.1\%) reported menstruation lasting less than seven days.

Table 3. Frequency Distribution of Respondents based on the Pain Presence

\begin{tabular}{cccc}
\hline No & Pain start & Frequency & Percentage (\%) \\
\hline 1 & Before Period & 14 & 41,1 \\
2 & During period & 20 & 58,9 \\
Total & & 34 & 100 \\
\hline
\end{tabular}

According to Table 3, the majority of respondents (20 female students, or 58.9\%) reported having menstrual pain during menstruation. However, a few students (14, or $41.1 \%$ ) reported menstrual pain before menstruation. 
Table 4. Frequency Distribution of Respondents Based on the Length of Menstrual Pain

\begin{tabular}{cccc}
\hline No & Duration & Frequency (f) & Percentage (\%) \\
\hline 1 & 1 day & 8 & 23,5 \\
2 & 2 day & 16 & 47,0 \\
3 & 3 days & 8 & 23,5 \\
4 & $>3$ days & 2 & 5,8 \\
Total & & 34 & 100 \\
\hline
\end{tabular}

According to table 4 , the majority of respondents (16 students or $47 \%$ ) had menstruation for more than two days, while a few (2 students or 5.8\%) had menstruation for more than three days.

Table 5. Frequency Distribution of Respondents Based on the Actions

\begin{tabular}{cllc} 
No & Actions & Frequency (f) & Percentage $(\%)$ \\
\hline 1 & left & 34 & 100 \\
2 & Take medicine & 0 & 0 \\
3 & Warm compress & 0 & 0 \\
4 & Drink herbs & 0 & 0 \\
5 & Take deep breath & 0 & 0 \\
Total & & 34 & 100 \\
\hline
\end{tabular}

As illustrated in Table 5, all responders tolerated their pain without taking any action (34 students or $100 \%)$.

Pre and Post Pain Scale in the Treatment Group

Table 6

Distribution of Pre and Post Menstrual Pain Scale in the Treatment Group

\begin{tabular}{lll}
\hline Pain Scale & Pre & Post \\
\hline Mean & 4.94 & 1,75 \\
Median & 5.00 & 2,00
\end{tabular}




\begin{tabular}{lcc} 
Modus & 5 & 3 \\
Deviation standard & 0.772 & 1.291 \\
Min-Max & $4-6$ & $0-3$ \\
\hline Wilcoxon Sign Rank Test & 0,000 \\
\hline
\end{tabular}

The pre-pain scale revealed that the average pain level of 17 responders was 4.94 with a median of 5.00, the greatest pain scale being 5, the lowest being 4 , and the highest being 6 .

The findings of the pre-pain scale assessment indicated that the average level of pain was 1.75 , the median level of pain was 2.00 , the greatest level of pain was 3 , the lowest level of pain was 0 , and the highest level of pain was 3. The Wilcoxon Sign Rank Test revealed $p=0.000<\alpha$ $=0.05$ in the treatment group, indicating that $\mathrm{H} 0$ is rejected and $\mathrm{H} 1$ is accepted. This demonstrates a considerable variation in the pain scale following the dispersal of turmeric stew.

\section{Pre and Post Menstrual Pain Scale in the Control Group}

Table 7. Distribution of Pre and Post Menstrual Pain Scale in the Control Group

\begin{tabular}{lll}
\hline Pain Scale & Pre & Post \\
\hline Mean & 5.25 & 3,75 \\
Median & 5.00 & 4,00 \\
Modus & 5 & 4 \\
Deviation standard & 0.577 & 1.183 \\
Min-Max & $4-6$ & $1-5$ \\
\hline \multicolumn{2}{l}{ Wilcoxon Sign Rank Test } & 0,000 \\
\hline
\end{tabular}

The pre-pain scale was calculated, and it was determined that the average pain level was 5.25 with a median value of 5.00 , the greatest pain scale being 5 , the lowest being 4 , and the highest being 6 .

The average postoperative pain score was 3.75 , with a median of 4.00 , the highest pain scale being 4 , the lowest pain scale being 1 , and the highest pain scale being 5 . In the control group, the Wilcoxon Sign Rank Test statistic was $\mathrm{p}=0.000<\alpha=0,05$, indicating that $\mathrm{H} 0$ is rejected, and $\mathrm{H} 1$ is accepted. This implies that there is a substantial difference in the pain scales before and after the control group received turmeric stew. According to the statistical analysis, it is concluded that administering turmeric stew to the control group has an effect on reducing the intensity of pain scale in female students with dysmenorrhea. 


\section{The Results Of The Difference In Pre And Post Pain Scale After The Dispersion Of Turmeric StewIn The Treatment And Control Group}

Table 8. Test of Differences in Pain Scale Pre and Post Giving after the Dispersion of Turmeric Stew in theTreatment and Control Group

\begin{tabular}{lcccc}
\hline & Group N & $\begin{array}{c}\text { Average } \\
\text { Pretest score }\end{array}$ & $\begin{array}{c}\text { Average } \\
\text { Post-test Score }\end{array}$ & Difference \\
\hline Treatment & 17 & 4.94 & 1.75 & 3,19 \\
Control & 17 & 5.25 & 3.75 & 1,5 \\
\hline
\end{tabular}

As shown in Table 8, the average difference between the pre-test and post-test of the treatment group is 3.19 , indicating that turmeric stew has a significant impact on the reduction in the severity of discomfort experienced by women suffering from dysmenorrhea. On the other hand, in the control group, the average difference between the pre-test and post-test scores was 1.5, indicating that the pain scale may be modestly reduced if the turmeric stew was not consumed.

\section{The Results Of The Different Effects Of Turmeric Stew On The Reduction Of Pain Scale In TheTreatment And Control Group}

Table 9. The Results of The Different Effects of Turmeric Stew on The Reduction of Pain Scale In TheTreatment and Control Group

\begin{tabular}{lcccc}
\hline Group & Mean Rank & Sum Of Ranks & Z & pValue \\
\hline Experimental & 24,22 & 371,50 & -4.177 & 0,000 \\
Control & 9,78 & 156,50 & & \\
\hline
\end{tabular}

Using the Mann-Whitney test, a p-value of $0.000(<0.05)$ was found. As a result, $\mathrm{H} 0$ is rejected, and $\mathrm{H} 1$ is accepted. This indicates that there is a difference in the efficacy of turmeric stew therapy on pain intensity reduction in female students with dysmenorrhea between the treatment and control groups.

\section{Pain Scale Before the Dispersion of Turmeric Stew to the Treatment and Control Group}

According to the findings, before therapy, using the NRS (Numeric Rate Scale) pain scale for students, objective signs of responders in the treatment group with an average pain of 
4.94 cramps in the lower abdomen to the waist were seen. Occasionally, the pain extends to the knees, resulting in diminished appetite. Additionally, pain impairs pupils' ability to control their emotions, and what is truly harmed is attention while learning and performing daily duties.

The average pain score in the control group was 5.25, with objective indications including pain extending from the lower abdomen to the waist, decreased physical activity, decreased appetite, irritation, and absence from school. The findings indicated that the respondents experienced moderate pain. Each woman experiences menstrual pain differently. Some women are somewhat disturbed, but others are sufficiently disturbed that they are unable to carry out everyday duties, necessitating respite and even absence from school or work: (Indriyani., 2013).

Dysmenorrhea is menstrual pain that is typically associated with cramping and is localized in the lower abdomen. Menstrual pain complaints can range from mild to severe. The study casts doubt on menstruation discomfort that is severe enough to need a woman to see a doctor for pain treatment. 11 This study corroborates Ningsih's (2011) findings on a scale of 46 (moderate pain). Additionally, the average age of respondents was 16.84. The majority of responses were between the ages of 17 and 18. The youngest is sixteen years old, and the oldest is eighteen. The findings of this study indicate that the younger the age, the greater the likelihood of experiencingdysmenorrhea, as the cervix is still tight compared to old age. This is consistent with Indriyani, D. (2013)'s assertion that a woman's cervix becomes broader as she ages. As a result, dysmenorrhea is extremely uncommon in elderly age: (Indriyani., 2013)

The studies discovered that when menstrual pain occurred, it occurred in 20 students $(58.9 \%)$, while 14 students experienced discomfort prior to menstruation (41.1\%). This explains why dysmenorrhea frequently develops during the first three days of menstruation. According to Gant \& Cunningham (2016), the most frequently seen symptoms include pain in the lower abdomen to the waist, which typically begins on day 1-2 and may include heartburn, pains, or prickles. The findings indicated that the majority of respondents (20 students or $58.9 \%$ ) had menstruation for seven days, while a minority (14 students or $41.1 \%$ ) had menstruation within seven days. As can be seen from the results above, the duration of menstruation is a risk factor for primary dysmenorrhea. Similarly, Kusmiran (2014) noted that while teenagers begin menstruating between the ages of 12 and 16, a normal menstrual cycle occurs every 22-35 days, with a menstrual duration of at least 2-7 days: (Kusmiran et al., 2014).

According to the researchers, the risk variables for dysmenorrhea in students at Senior High School 1 East Pamona, Poso Regency, are age, menarche age, and menstrual cycle duration. Similarly, Indriyani (2013) discussed the risk factors for primary dysmenorrhea. According to her, someone is more likely to have dysmenorrhea if they reached menarche earlier in life, have never been pregnant, or have given birth. Additionally, menstruation lasts longer than typical: (Indriyani., 2013). 


\section{Pain Scale After the Dispersion of Turmeric Stew to the Treatment and Control Group}

According to the findings of a study conducted on 17 female students who were treated with turmeric acid prior to receiving therapy, the average level of discomfort was 4.94. The average pain scale fell to 1.75 following the dispersion of the turmeric acid. Certain objective signals were observed, including the ability to communicate, a decrease in pain, and the ability to perform activities comfortably. This finding reveals that turmeric stew has a significant effect on pain scale reduction in female students with dysmenorrhea. Another study conducted by Marlina (2012) demonstrated that turmeric drink had an influence on the level of primary dysmenorrhea discomfort in adolescents attending Senior High School 1 Tanjung Mutiara, Agam Regency $(\mathrm{P}=0.000), \mathrm{p}<0.05$ : (Marlina E., 2012).

This is consistent with McPhee and Ganong's (2013) opinion that turmeric contains curcumin and essential oils that have a similar effect to analgesic drugs in terms of reducing dysmenorrhea pain by inhibiting the biosynthesis of prostaglandins and thus blocking pain impulses originating from the pain cortex in the medulla oblongata: (McPhee et al.,2013). Turmeric contains bioactive compounds that have numerous health advantages. These molecules are referred to as curcuminoids and essential oils and have been shown to have antiaging, anti-senile, antimicrobial, antiseptic, and anti-inflammatory properties:(Hartati et al.,2013) The natural components in turmeric drink can help alleviate primary dysmenorrhea symptoms in their own unique ways. Curcumin and anthocyanins operate by suppressing the cyclooxygenase process, thereby preventing or reducing inflammation. As a result, uterine contractions will be reduced or even inhibited. Curcumin inhibits uterine contractions by decreasing the entrance of calcium ions $(\mathrm{Ca} 2+)$ into calcium channels found in uterine epithelial cells. The tannins, saponins, sesquiterpenes, alkaloids, and phlobotamines in these plants have an effect on the autonomic nerve system, which then affects the brain, so reducing uterine contractions. Additionally, curcumenol, as an analgesic, inhibits the excessive release of prostaglandins.

While 17 female students in the control group experienced an average pain scale of 5.25 on the first day, the average pain scale reduced to 3.75 on day three. We acquired objective signs from responders who frequently grinned. They experienced some discomfort in the lower abdomen but were able to engage in physical activity and regain their appetite. This change demonstrates that, in the absence of the turmeric stew, it is possible to somewhat reduce the pain scale in female students with dysmenorrhea.

\section{Differences in Pre and Post Pain Scale After the Dispersion of Turmeric Stew}

According to Table 8, the average difference between pretest and post-test scores is 3.19 in the treatment group, whereas the average difference between pretest and post-test scores is 1.5 in the control group. Despite the fact that the treatment group obtained more than the control group, both groups reported changes on the pain scale. 
Curcuminoids are the compounds in turmeric that give it its color and medicinal benefits. This chemical is a potent antioxidant. It is hypocholesterolemic, cholagogue, choleretic, bacteriostatic, spasmolytic, antihepatotoxic, and anti-inflammatory in nature. Additionally, turmeric contains $6.3 \%$ protein, $5.1 \%$ fat, $3.5 \%$ minerals, $69.4 \%$ carbs, $13.1 \%$ moisture, $45-55 \%$ vitamin C, mineral salts (iron, phosphorus, and calcium), and 5.8\% essential oils: (Yusuf., 2012).

\section{Differences in the Effect of Giving Turmeric Stew on Reducing Pain Scale in Students of Senior High School 1 East Pamona, Poso Regency}

The Mann-Whitney test revealed a p-value of $0.000(<0.05)$ for the difference in pain scale following the dispersion of turmeric stew. It denotes that $\mathrm{H} 0$ has been rejected and $\mathrm{H} 1$ has been approved. These results indicate that there is a difference in the effect of turmeric stew therapy on the reduction of pain scale in students of Senior High School Negeri 1 East Pamona, Poso Regency compared to those who are not given turmeric stew therapy. According to the analysis, the average drop in the pain scale for the treatment group is 24.22 , whereas the average decrease in the pain scale for the control group is 9.78 . These findings indicate that turmeric stew plays a significant role in pain reduction.

The Mann-Whitney test revealed a p-value of $0.000(<0.05)$ for the difference in pain scale following the dispersion of turmeric stew. It denotes that $\mathrm{H} 0$ has been rejected, and $\mathrm{H} 1$ has been approved. The findings indicate that there is a difference in the effect of turmeric stew therapy on pain scale reduction in students of Senior High School Negeri 1 East Pamona, Poso Regency compared to those who are not given turmeric stew therapy.

The findings of this study corroborate Silvia Intan Suri's (2014) study on the effect of turmeric on menstruation pain in grade 1 teenage students at Nurul Yaqin Islamic Boarding School in Pakandangan District 6, Padang Pariaman Regency in 2014. After doing statistical tests, a p-value of 0.000 was observed. This suggests that the p-value is $\leq 0.05$, indicating that $\mathrm{Ha}$ is accepted, implying that there is a substantial effect prior to and following consumption of turmeric stew: (Silvia., 2014).

The findings of this study are corroborated by Marsaid et al. (2017) in their investigation on the efficacy of turmeric extract in reducing dysmenorrhea in adolescent girls. The results indicated that the majority of responders, 14 in total, had moderate pain prior to receiving turmeric extract $(53.8 \%)$. Meanwhile, the majority of respondents (19 respondents or $73.1 \%$ ) reported no pain following the dispersion of turmeric acid extract. The Wilcoxon Matched Pairs statistical test revealed that $\rho$-value $0.000 .<\alpha(0.05)$. Ho was then rejected, whereas Ha was accepted. Turmeric acid extract significantly alleviates dysmenorrhea in young women in Tambang Village, Pudak District, Ponorogo Regency: (Marsaid et al., 2017)

Turmeric stew has a different effect than non-turmeric stew because it contains curcumin, anthocyanins, curcumenol, tannins, saponins, sesquiterpenes, alkaloids, and phlobotamins. Meanwhile, even if no medication is administered, the discomfort will lessen due to the body's tolerance for pain. The magnitude shift, however, is insignificant in the absence of support. The pain scale may fluctuate on day 3 of menstruation as prostaglandin hormone levels decrease. 
Overcoming menstruation discomfort (dysmenorrhea) can be accomplished with the administration of an analgesic, anti-inflammatory, and herbal medicine therapy produced from plant materials. Certain herbs, including turmeric, tamarind, cinnamon, cloves, and ginger, are believed to alleviate pain: (Anurogo et al., 2011)

Turmeric includes curcumin and essential oils that have a similar effect to analgesic medicines in lowering dysmenorrhea discomfort. Turmeric works by suppressing the biosynthesis of prostaglandins, so blocking pain signals emanating from the pain cortex in the medulla oblongata.

\section{Conclusions}

Based on the results, it can be concluded that there is a significant effect of drinking turmeric stew on decreasing the pain scale of dysmenorrhea.

\section{Acknowledgements}

The researchers extend their gratitude to all parties who have contributed to the completion of this research.

\section{Conflict of Interest}

All Authors declare no conflict of interest and agree with the content of the manuscript

\section{References}

Anurogo, D \& Wulandari, A. (2011). Cara jitu mengatasi nyeri haid. Yogyakarta: Penerbit Andi.

Desfietni, V. (2012). Efektifitas kombinasi pemberian teknik nafas dalam dan terapi music instrumental terhadap penurunan intensitas nyeri (dismenorea) pada remaja putri di SMPN 4 Kuantan Hilir. Tidak dipublikasikan: Skripsi PSIK Sekolah Tinggi Ilmu Kesehatan Hang Tuah Pekanbaru.Depkes RI.(2013).

Febriana, Kartika. (2013). Uji Aktivitas Antioksidan Eksrak dan fraksi daun cocculus orbiculatus (L) DC. Dengan metode DPPH dan Fraksi Identifikasi Golongan Senyawa Kimia Dari Fraksiyang aktif' FMIPA UI, Depok

Gant, Norman dan Cunningham, Gary. 2016. Dasar - Dasar Ginekologi \& Obstetri. Jakarta : EGC.

Hartati, S.Y., Balittro. (2013). Khasiat Kunyit Sebagai Obat Tradisional dan Manfaat Lainnya. Warta Penelitian dan Pengembangan Tanaman Industri. Jurnal Puslitbang Perkebunan. $19: 5-9$.

Hasil Riskesdas 2013-Departemen Kesehatan Republik Indonesia. Diakses dari :HTTP://www.depkes.go.id/resource/download/general/Hasil\%20Riskesdas\%20213.pdf

Indriyani, D. 2013. Keperawatan Maternitas. Graha Ilmu; Yogyakarta.

Kusmiran, Eny. (2014). Kesehatan Reproduksi Remaja dan Wanita. Jakarta: Salemba Medika. Lie, S. (2004). Terapi vegetarian untuk penyakit kewanitaan. Jakarta: Prestasi Pustaka karya. Mansur, H. (2009). Psikologi ibu dan anak untuk kebidanan. Jakarta: Salemba Medika.

Marlina E, (2012), Pengaruh Minuman Kunyit Asam Terhadap Tingkat Nyeri Dismenorea Primer Pada remaja Putri di SMA Negeri 1 Tanjung Mutiara Kabupaten Agam, Skripsi, Fakultas Keperawatan Universitas Andalas. Nair

Marsaid; Nurjayanti; Rimbaga, Yocykha, Ari. (2017). Efektifitas pemberian ekstrak kunyit asam 
terhadap penurunan dismenore pada remaja putri di desa tambang kecamatan pudak kabupaten ponorogo. Jurnal. Global Health Science. Vol. 2. Ponorogo

McPhee, Stephen dan Ganong, William. (2013). Patofisiologi Pemyakit Pengantar Menuju Kedokteran Klinis. Jakarta : EGC.

Ningsih R. (2011). Efektivitas Paket Pereda Terhadap Intensitas Nyeri Pada Remaja Dengan Disminore Di SMAN Kemanatan Gurup. Jakarta: Universitas Indonesia.Tesis

Nur Baiti, Ulfa. (2018). Pengaruh Pemberian Minuman Kunyit Asam Terhadap PerubahanSkala Nyeri Pada Siswi Kelas VII dengan Dismenore Primer di MTsN 6 Madium. (Jurnal) Yusuf, (2012).

Reeder, dkk. (2011). Keperawatan Maternitas Kesehatan Wanita, Bayi dan Keluarga. Edisi 8. Jakarta: EGC.

Sarwono. S.W. 2011. Psikologi Remaja. Jakarta: PT Raja Grafindo Persada

Silvia Intan Suri, (2014) Pengaruh minuman kunyit terhadap penurunan tingkat nyeri menstruasi pada remaja putri kelas 1 di pondok pesantren nurul yaqin pakandangan kecamatan 6 lingkung kabupaten padang pariaman tahun 2014. Jurnal Kesehatan Indonesia.

Tandi, H. 2015. Kitab Tanaman Berkhasiat Obat 226 Tumbuhan Obat Untuk Penyembuhan Penyakit dan Kebugaran Tubuh. Octopus Publishing House. Yogyakarta.

WHO. (2013). Data Jumlah Penderita Dysmenorrhea. www.who.int/gho/en/. Diakses pada 8 November 2017

Yusuf, (2012). Khasiat super minuman alami tradisional beras kencur dan kunyit asam menyehatkan dan menyegarkan tubuh tanpa efek samping. Yogyakarta : Diandra Pustaka Indonesia. 